COMPUTATIONAL RESEARCH PROGRESS IN APPLIED SCIENCE \& ENGINEERING (CRPASE)

\title{
The Effects of Green Roof on Heat Loss and Energy Consumption in the Buildings
}

\author{
Merve Tuğba Ercan ${ }^{1}$, Merve Tuna Kayili ${ }^{2 *}$, Bahar Sultan Qurraie ${ }^{2}$ \\ ${ }^{1}$ Institue of Graduae Sciences, Karabuk University, Karabuk, Turkey \\ ${ }^{2}$ Department of Architecture, Karabuk University, Safranbolu, Karabük, Turkey
}

\begin{tabular}{ll}
\hline Keywords & Abstract \\
\cline { 2 - 3 } $\begin{array}{l}\text { Green Roof, } \\
\text { Heat Loss, }\end{array}$ & $\begin{array}{l}\text { Thanks to the developing technology and building material science, while the roof is an } \\
\text { energy Consumption, } \\
\text { Terrace Roof. }\end{array}$ \\
$\begin{array}{l}\text { an area that provides living spaces outside the building and can also be used as an activity. } \\
\text { Green roofs are critical systems that improve the energy performance, air quality, and urban } \\
\text { ecology without additional equipment, produce innovative solutions to the problems caused } \\
\text { by rainwater and are located in sustainable buildings with these features. Green roofs are } \\
\text { divided into two groups as intensive and extensive green roofs. These systems, which vary } \\
\text { according to the thickness of the soil, may have a negligible effect in preventing the heat } \\
\text { loss of the building. In this study, the impact of green roofs on energy performance and their } \\
\text { role in preventing heat losses were analyzed through a sample social building. As a result, } \\
\text { it was determined that green roofs avoid heat loss by 83\% compared to the terrace roof. }\end{array}$ \\
\hline
\end{tabular}

\section{Introduction}

Energy resources are gradually decreasing, the population is increasing, and intense construction disrupts the balance of nature $[1,2]$. Increasing energy use in construction has paved the way for ecological building designs that use energy efficiently in cities. Together with the developing technology, this situation the green roof has been brought to the agenda in the search for architecture, aesthetics, and ecology. Green roofs have provided people with an easy-toreach green space and the opportunity to create a space that reduces the adverse effects of the external environment.

Thanks to the developing technology, the roof has ceased to be a building element that loses energy and has become a component that provides residues to the ecosystem. Thanks to sustainable use, green roofs have turned into a place that offers both a living space outside the building and a space for movement. With these features, the concept of the green roof have become ecologically, economically, and socially essential and its classical definition[3-5]. In short, green roofs increase the energy performance of the building, improve the air of the city, offer new solutions for rainwater, and develop the sustainable building concept with all these features [6].

According to research on green buildings, compared to roofs designed according to traditional methods in the design and construction of buildings with sustainability criteria, green roofs save between $24 \%$ and $50 \%$ [7, 8] in energy

${ }^{*}$ Corresponding Author: Merve Tuna Kayili

E-mail address: mervetunakayili@karabuk.edu.tr

Received: 2 December 2021; Revised: 22 December 2021; Accepted: 27 December 2021

https://doi.org/10.52547/crpase.7.4.2422

Academic Editor: Vahid Najafi Moghadam Gilani

\footnotetext{
Please cite this article as: M. T. Ercan, M. T. Kayili, B. S. Qurraie, The Effects of Green Roof on Heat Loss and Energy Consumption in the Buildings, Computational Research Progress in Applied Science \& Engineering, CRPASE: Transactions of Civil and Environmental Engineering 7 (2021) 1-8, Article ID: 2422.
} 
consumption, produce between $33 \%$ and $39 \%$ less carbon dioxide $[9,10]$, and provides $30-50 \%$ less water consumption $[11,12]$.

In addition, it has been observed that green roofs are $70 \%$ more efficient in the production of solid waste and $13 \%$ more efficient in maintenance and repair costs [13-15]. The American Green Building Council (USGBC) [16] stated that an average green building could save 32\% [17].

Green and ecological roofs are covered with soil and plant layers in the upper layer. Between the roof sheet and the green part, there are layers such as drainage, root holding layer, moisture holding layer, water insulation, heat insulation [18-20]. Green roofs are divided into two as dense and widespread green roofs according to the depth of the layer carrying the plant and the type of vegetation. These two concepts were created by Dunnet and Kinsbury [21]. The depth of the intensive green roof plant carrier layer is between $20-60 \mathrm{~cm}$ roof type [22]. The extensive green roof is the type of roof planted less sparsely and whose soil thickness is in the range of $7-10 \mathrm{~cm}[23,24]$, which does not require much maintenance, and even water needs are selected [25] for a longer life by choosing plants [26].

Sustainable systems have a significant role in protecting the natural balance [27], which is disrupted by climate change. Green roofs play an essential role in ensuring sustainability [28], especially in places where intense urbanization and green space are reduced. Green roofs offer a solution to protecting the natural balance in the face of rain and floods, high air temperature, air pollution, and even the noise of cities, reducing the adverse effects of climate change [29]. According to Green Roofs for Healthy Cities (GRHC) data [30], $75 \%$ of the surfaces of cities are covered with impervious surfaces, and roofs constitute a significant part of this. Against this situation in the cities, green roofs also provide aesthetic benefits. Thanks to the soil and plant layer on the green roofs $[3,31]$, vegetation forms a living space for birds and insects, reduces air pollution by reducing the rate of carbon dioxide in the air [32], cleans the air by producing oxygen, and plays an active role in reducing air temperature by contributing to evaporation.

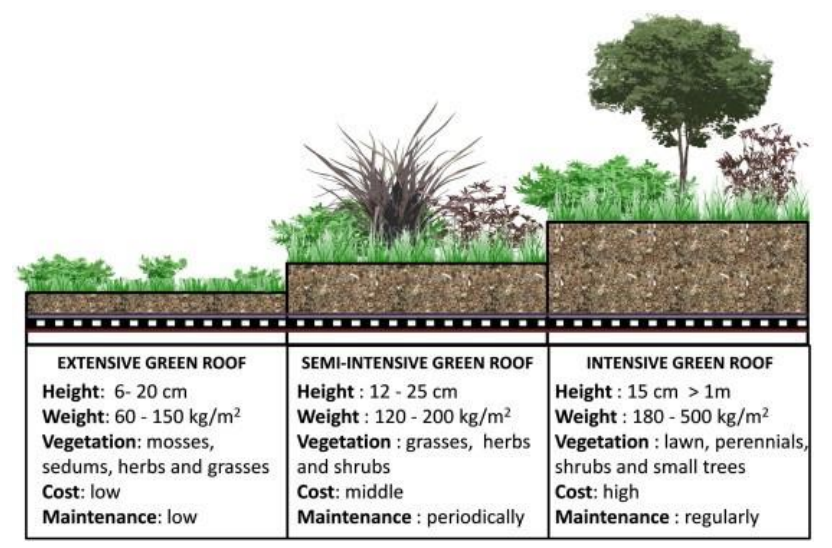

Figure 1. Summary of green roof types based on the International Green Roof Association (IGRA) classification [33]

In recent years, scientific studies have been carried out on ecological and energy-efficient building design and their contribution to building energy performance. Much research has been done on green roofs and their positive effects on energy sustainability. In the studies [34-38], the impact of green roofs on the heating and cooling loads of the building was investigated. The other research papers [39-46] refer to the analysis of the thermal and energy performance of the green roof. Further study about green roof systems installed in a nursery school building in Athens [47] energy performance evaluation showed a significant reduction in cooling load of the building during summer. However, these studies did not examine green roof types. This study aims to determine both the energy performance superiority of green roofs over traditional flat terrace roofs and the energy performance superiority of intensive and extensive green roofs over each other. So, the sample building will be simulated in 3 different ways as flat terrace roof (FTR), extensive green roof (EGR), and intensive green roof (IGR), and contribution to energy performance will be discussed. The study is expected to guide architects, practitioners, and designers in the roofing industry in choosing a roof type.

\section{Case Study}

The new campus of the Bartın University is located in Kutlubey Yazıcilar district, $13 \mathrm{~km}$ from the center of Bartın province. The Living Center (Figure 2), which has a floor session of $2387.95 \mathrm{~m}^{2}$, is single-story, the floor height is 6 meters, and the maximum height is 8.5 meters with roof parapets and coating materials. The terrace roof is $2314 \mathrm{~m}^{2}$.

The windows used in the building are Low-E doubleglazed SC:0.2 specifications, together with an aluminum frame, while the doors are double-glazed with an aluminum frame. The thermo-optic properties of doors and windows are given in Table 1. The floor, wall, and roof components and properties of the building constructed with a reinforced concrete system are shown in Table 2.

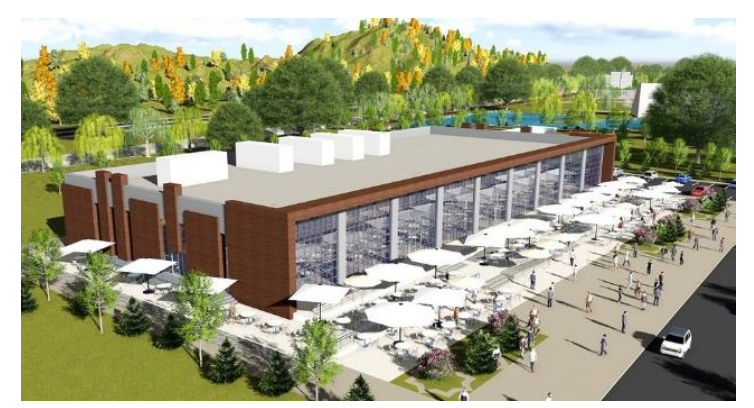

Figure 2. Bartın University Life Center [48]

Table 1. U-R-SGHC values of doors and windows

\begin{tabular}{cccc}
\hline $\begin{array}{c}\text { Building } \\
\text { Element }\end{array}$ & $\begin{array}{c}\mathrm{U} \\
\left(\mathrm{W} / \mathrm{m}^{2} \mathrm{~K}\right)\end{array}$ & $\begin{array}{c}\mathrm{R} \\
\left(\mathrm{m}^{2} / \mathrm{KW}\right)\end{array}$ & SGHC \\
\hline Window & 0.475 & 2.103 & 0.24 \\
Door & 4.116 & 0.242 & - \\
\hline
\end{tabular}

In addition to the FTR of the building, two different alternatives were examined: an EGR and an IGR. The applied EGR (Table 3) is $16.8 \mathrm{~cm}$ high, while the IGR (Table 4) is $62.3 \mathrm{~cm}$ high. FLORAXX series of Delta ${ }^{\circledR}$ brand belonging to Dorken company was used for green roofs. The layers used in green roofs and their heights are shown in Table 3 and Table 4. 
Table 2. Wall, floor and roof components and features of the building

\begin{tabular}{|c|c|c|c|c|}
\hline \multicolumn{5}{|c|}{ Components and Features } \\
\hline & $\begin{array}{l}\text { Thickness } \\
\text { (m) }\end{array}$ & $\begin{array}{l}\text { Conductivity } \\
(\mathrm{W} / \mathrm{mK})\end{array}$ & $\begin{array}{l}\text { Intrinsic Heat } \\
\left(\mathrm{J} / \mathrm{g}^{\circ} \mathrm{C}\right)\end{array}$ & $\begin{array}{l}\text { Density } \\
\left(\mathrm{kg} / \mathrm{m}^{3}\right)\end{array}$ \\
\hline \multicolumn{5}{|l|}{$\begin{array}{c}\text { Floor } \\
\text { Covering }\end{array}$} \\
\hline Marble & 0.02 & 2.9 & 0.8400 & 2750 \\
\hline Handle & 0.03 & 0.720 & 0.9200 & 1650 \\
\hline $\begin{array}{l}\text { Reinforced } \\
\text { Concrete } \\
\text { Paving. }\end{array}$ & 0.15 & 1.046 & 0.6570 & 2300 \\
\hline \multicolumn{5}{|l|}{ Roofing } \\
\hline Gravel & 0.03 & 0.360 & 0.8400 & 1840 \\
\hline $\begin{array}{l}\text { Polystyrene } \\
\text { Foam } \\
\text { Insulation }\end{array}$ & 0.01 & 0.035 & 1.4700 & 23 \\
\hline $\begin{array}{l}\text { Geotextile } \\
\text { Felt }\end{array}$ & 0.02 & 0.190 & 0.9500 & 960 \\
\hline $\begin{array}{l}\text { Water } \\
\text { isolation }\end{array}$ & 0 & 1.150 & 0.8400 & 2330 \\
\hline $\begin{array}{c}\text { Slope } \\
\text { Concrete }\end{array}$ & 0.02 & 0.720 & 0.9200 & 1650 \\
\hline $\begin{array}{l}\text { Reinforced } \\
\text { Concrete }\end{array}$ & 0.15 & 1.046 & 0.6570 & 2300 \\
\hline $\begin{array}{l}\text { Paving. } \\
\text { Plaster }\end{array}$ & 0.03 & 0.720 & 0.9200 & 1650 \\
\hline \multicolumn{5}{|l|}{ Wall } \\
\hline $\begin{array}{l}\text { Compact } \\
\text { Container }\end{array}$ & 0.05 & 0.106 & 1.4200 & 552 \\
\hline Rock Wool & 0.02 & 0.034 & 0.7100 & 200 \\
\hline $\begin{array}{c}\text { Exterior } \\
\text { Plaster }\end{array}$ & 0.03 & 0.720 & 0.9200 & 1650 \\
\hline Wall & 30 & 0.540 & 0.8400 & 1550 \\
\hline Roughcast & 0.02 & 0.720 & 0.9200 & 1650 \\
\hline Plaster & 0.02 & 0.510 & 0.9600 & 1120 \\
\hline
\end{tabular}

Table 3. Extensive Green Roof Layers (Adapted from [21, 26, 4955])

\begin{tabular}{cc}
\hline \multicolumn{2}{c}{ Extensive Green Roof Layers } \\
\hline Layer & Thickness $(\mathrm{cm})$ \\
\hline Plant Layer & 3 \\
Soil Layer & 10 \\
Filter Layer & 0.2 \\
Drainage & 2.5 \\
Moisture Retaining Layer & 0.1 \\
Root Holder Layer & 0.5 \\
Separator Felt & 0.5 \\
Water isolation & 0 \\
\hline
\end{tabular}

Table 4. Intensive Green Roof Layers [Adapted from [26, 56-59]]

\begin{tabular}{cc}
\hline \multicolumn{2}{c}{ Intensive Green Roof Layers } \\
\hline Layer & Thickness $(\mathrm{cm})$ \\
\hline Plant Layer & 20 \\
Soil Layer & 25 \\
Filter Layer & 0.2 \\
Drainage & 6 \\
Moisture Retaining Layer & 0.1 \\
Root Holder Layer & 0.5 \\
Separator Felt & 10 \\
Water isolation & 0.5 \\
Plant Layer & 0 \\
\hline
\end{tabular}

The temperate marine climate (Black Sea Climate) prevails in Bartın, with hot summers and cool winters. Its proximity to the sea and the mountain ranges, which are not very high, are parallel to the coast generally cause a decrease in temperature differences on the coastline, increased humidity, and air masses coming from the Balkans [60]. The weather data of Bartın can be shown in Figure 3.

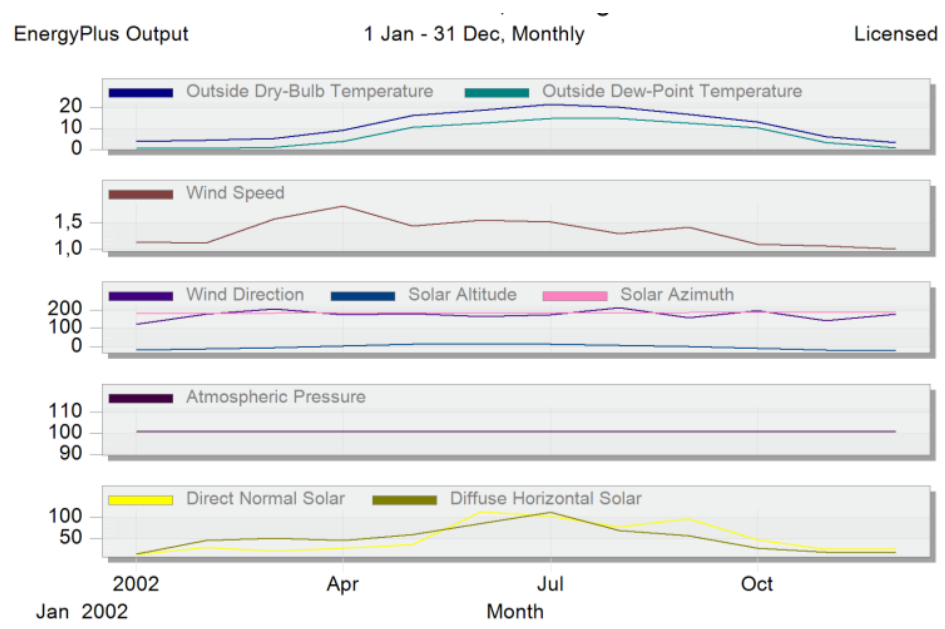

Figure 3. Weather data of Bartın exported from Design Builder software

Modeling and simulation of building energy have been done in Design Builder Software to perform the relevant analyses and observe the differences of the three models. Design Builder Software [61], which is one of the most advanced and up-to-date software in this field and simulating heating and cooling systems, has dynamically the ability to model different energy uses of the building, including heating, cooling, lighting, appliances, water consumption, etc. According to the use of the building, its working hours are from Monday to Saturday from 8:00 AM to 6:00 PM, and 
the operating time of $\mathrm{HVAC}$ is considered according to this time. The windows are closed in all seasons, and comfortable temperatures are set according to ASHRAE standards. The front outlooks of rendered models are shown in Figure 4.

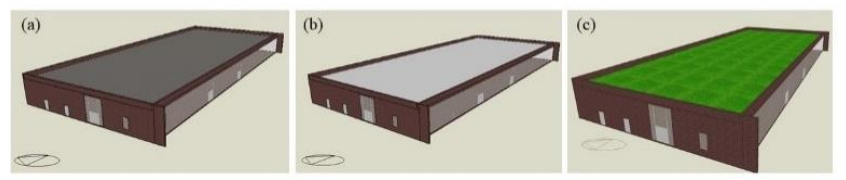

Figure 4. Rendered images modeled in Design Builder a)FTR b)EGR c) IGR

\section{Results}

In the energy simulations made for the Bartın University Life Center building, the heating load, cooling load, and energy consumption used for ventilation was considered within each roof type. Then the energy consumption ratio was calculated between the three roof types and was evaluated in terms of efficiency.

So, at first, it was made energy transfer calculations seen in Figures 5, 6, and 7 to determine the size of the heating and cooling loads.
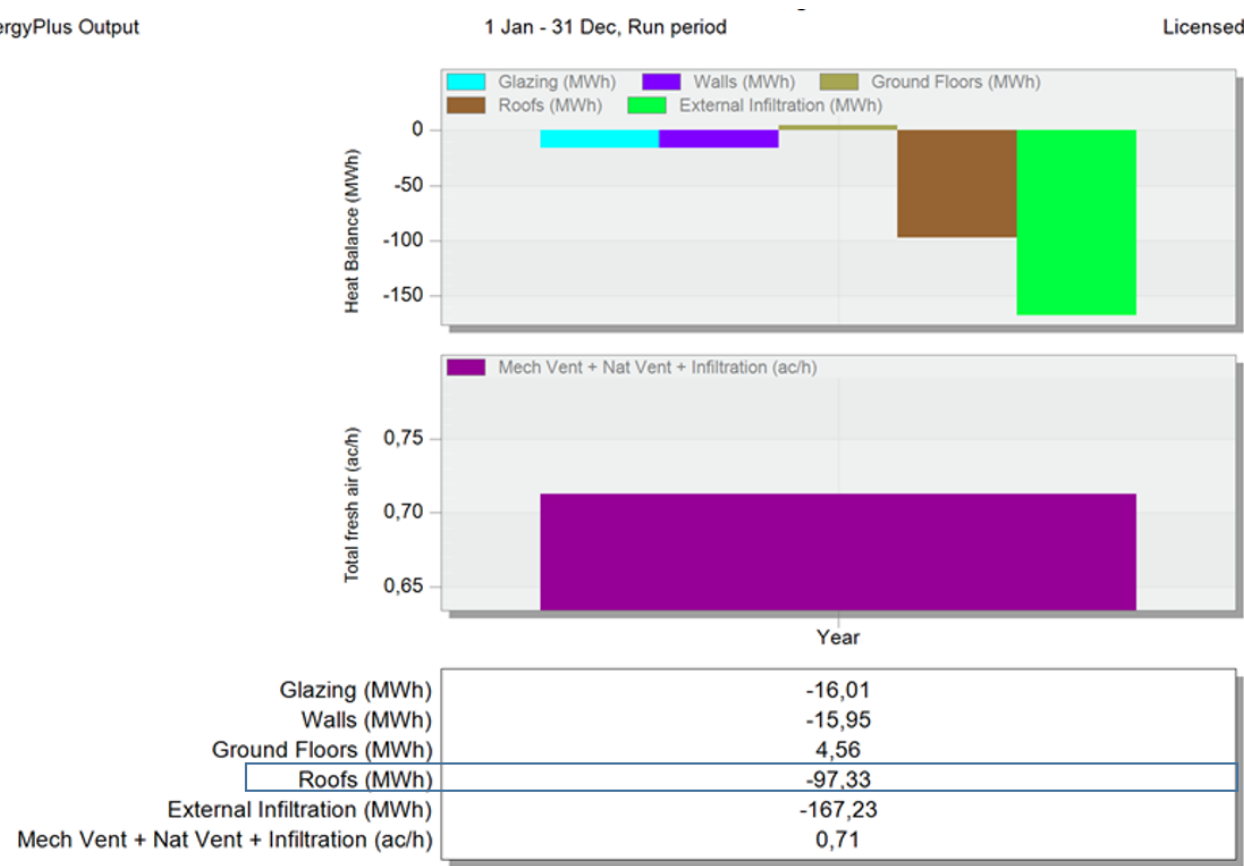

Figure 5. FTR heating design and the amount of roof heat loss compared to other exterior surfaces
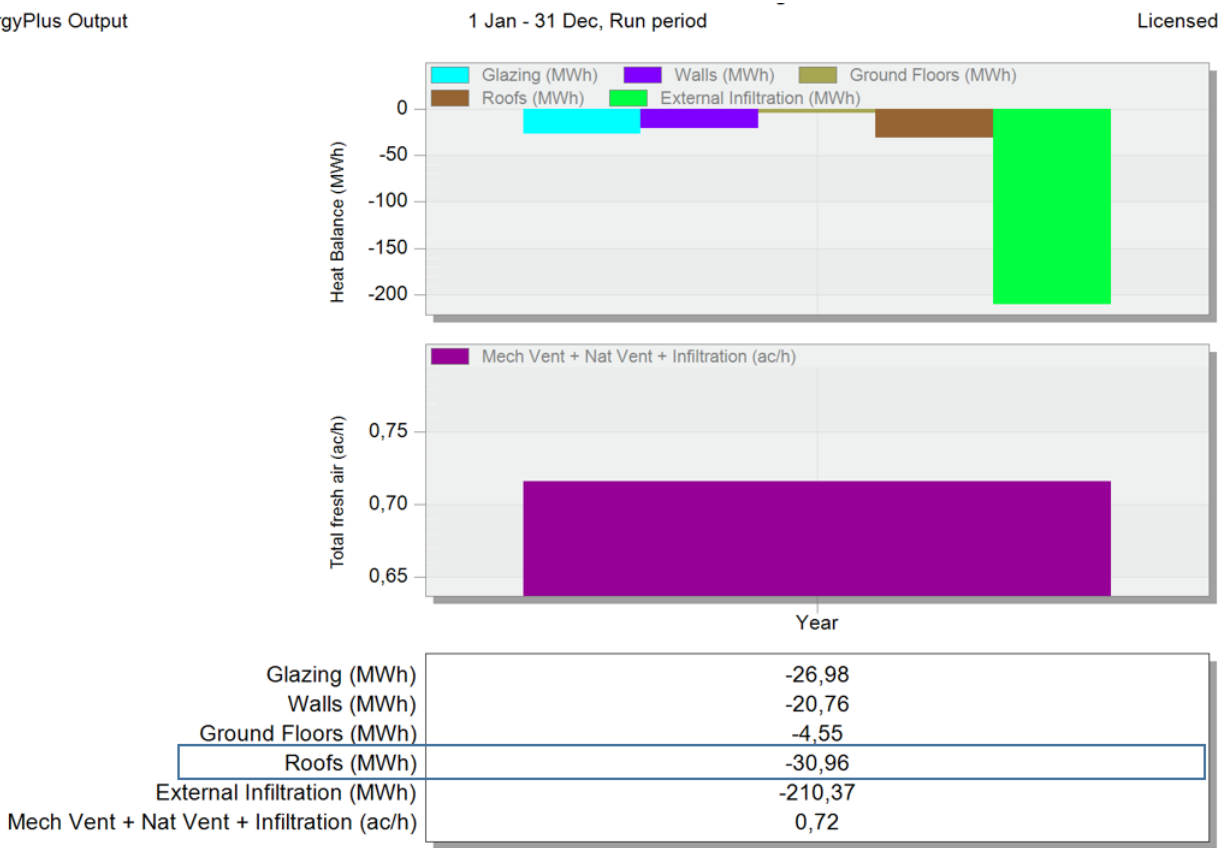

Figure 6. EGR heating design and the amount of roof heat loss compared to other exterior surfaces 
According to Figures 5-7, the energy loss by the roof in the terrace roof model is $97.33 \mathrm{kWh}$, and in the EGR and IGR roofs are 30.96 and $16.65 \mathrm{kWh}$, respectively which is a significant reduction. According to the decrease in the amount of energy lost from the roof, there is a decrease in the heating and cooling load of the building. The energy consumption of the building can be seen in Figure 8.
The heating load on the FTR in January and December are the maximum total of 40868 and $34976 \mathrm{kWh}$. This value in the same month (January) in EGR and IGR are 33772 and $31876 \mathrm{kWh}$, respectively. The cooling load is the maximum in July, and its amount is 11822,5708 , and $5548 \mathrm{kWh}$ in FTR, EGR, and IGR, respectively. The gas and electricity consumption of the building without considering the lighting energy is shown in Figure 9.

EnergyPlus Output
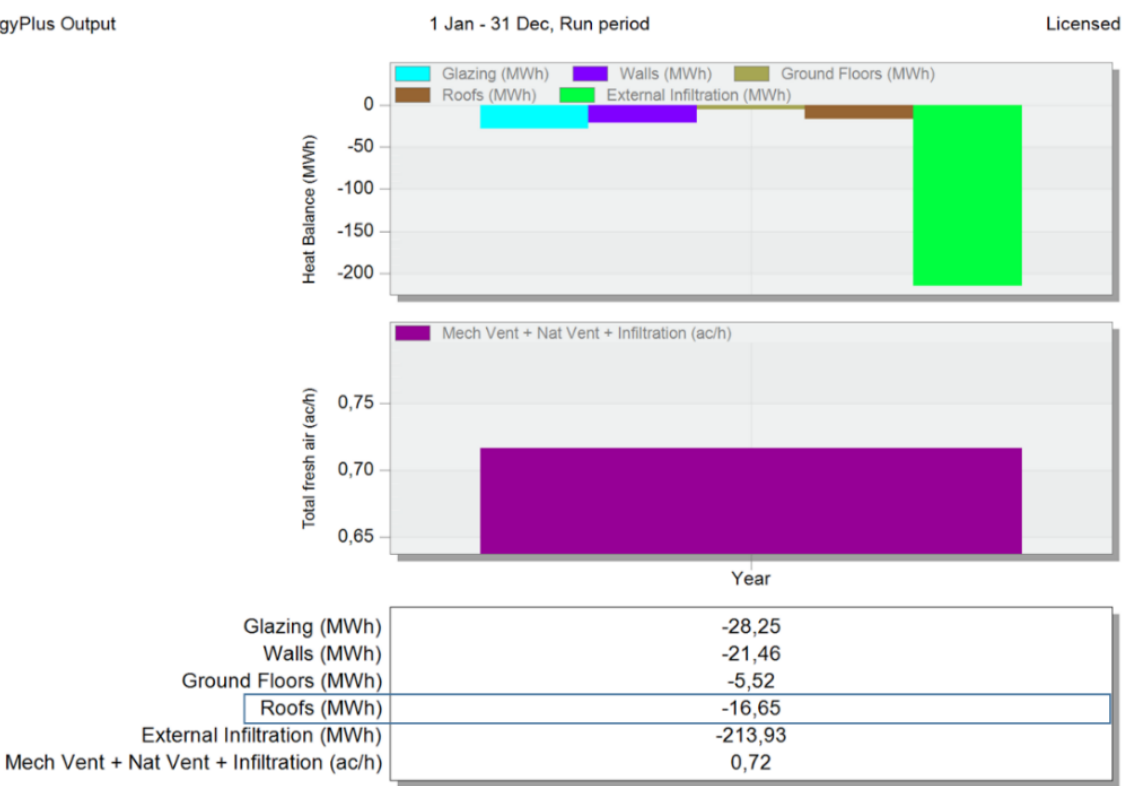

Figure 7. IGR heating design and the amount of roof heat loss compared to other exterior surfaces
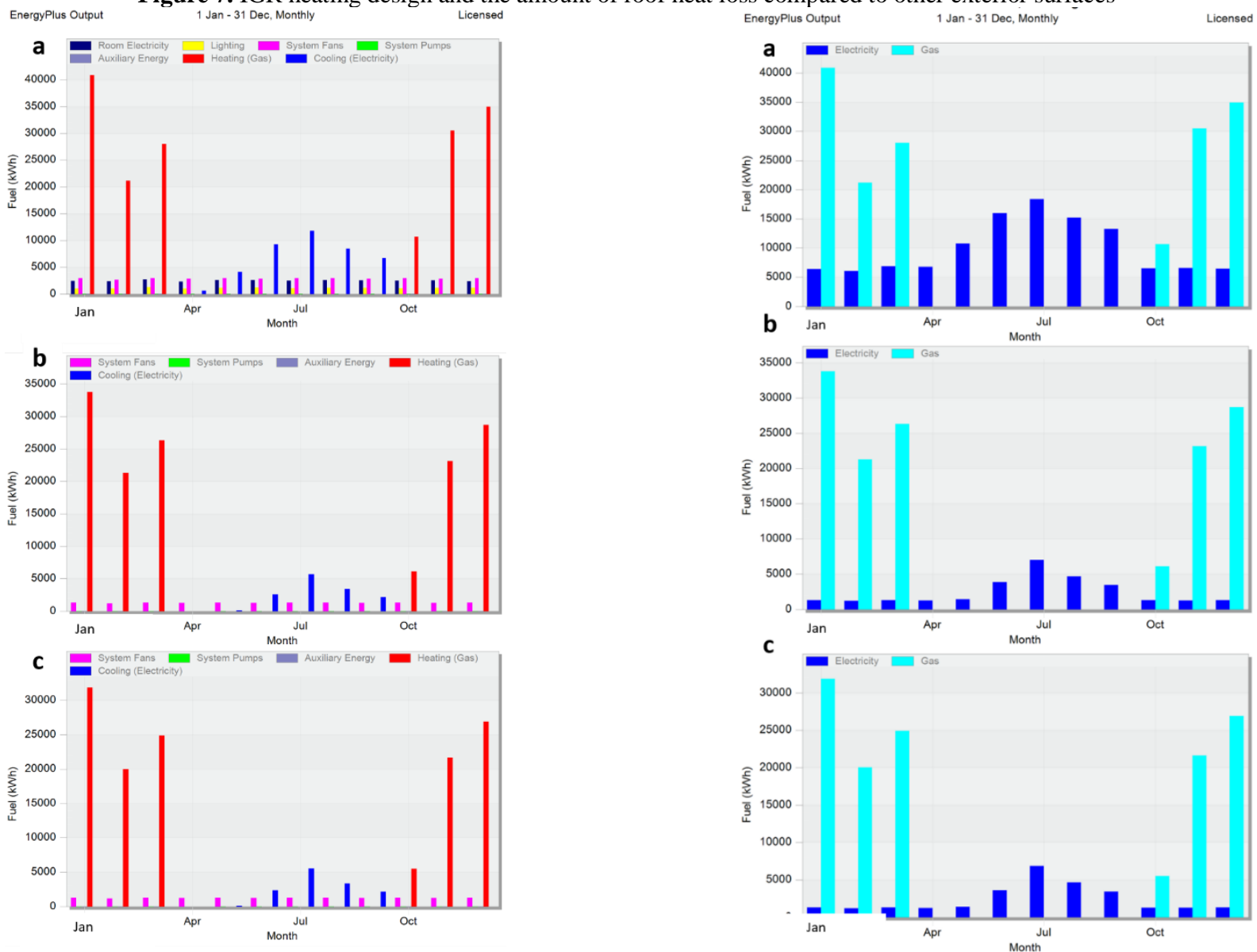

Figure 8. The energy consumption of the building. a) FTR, b) EGR, c) IGR

Figure 9. Total Monthly Energy Consumption. a) FTR, b) EGR, c) IGR 
Total energy consumption is like graphs, ignoring the lighting data. There is a decrease of $8000 \mathrm{kWh}$ in gas consumption in January and approximately $6000 \mathrm{kWh}$ in electricity consumption in August. $\mathrm{CO}_{2}$ emission from energy consumption is like the graphs below.
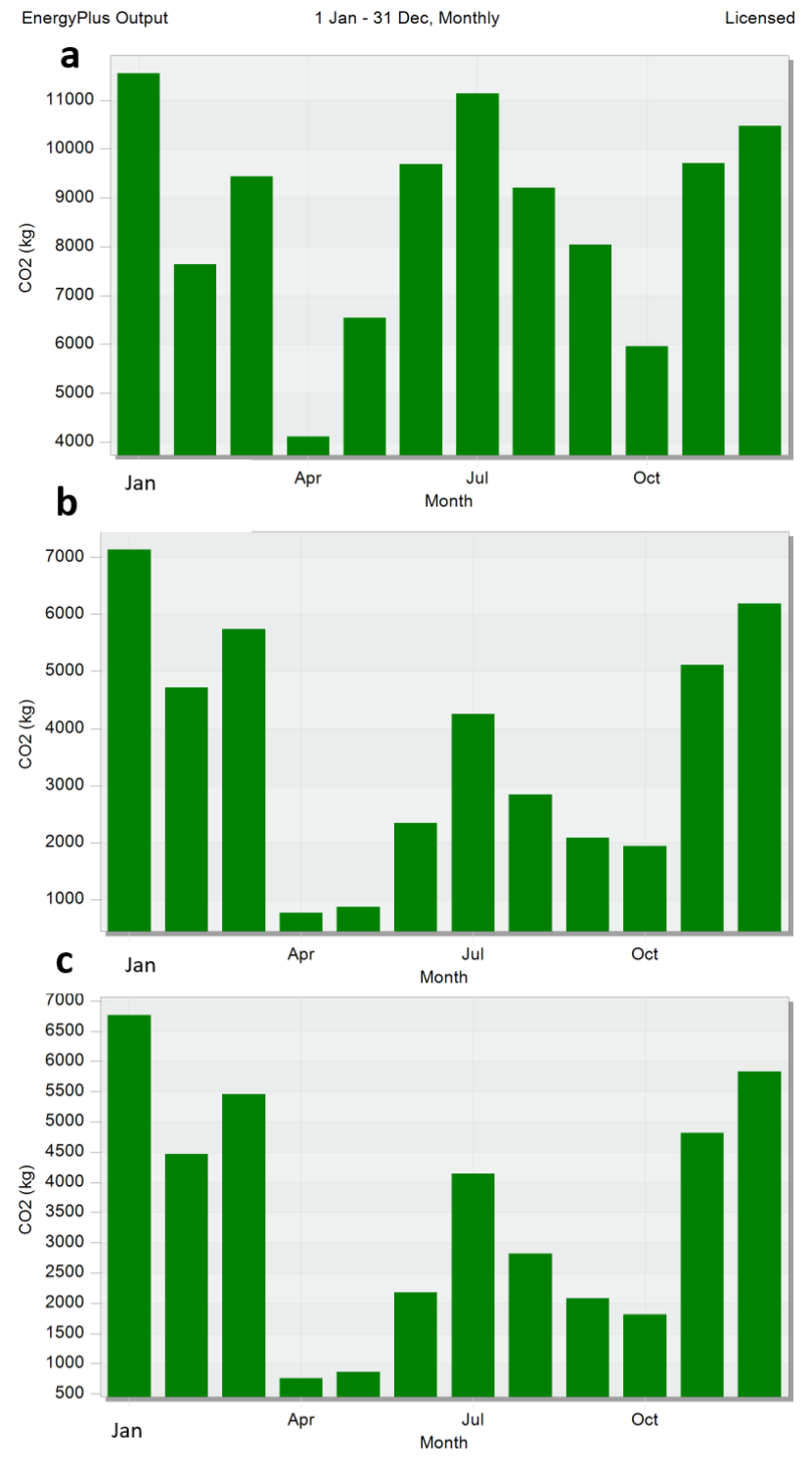

Figure 10. $\mathrm{CO}_{2}$ emission from energy consumption a) FTR b) EGR c) IGR

\section{Conclusions}

Thanks to the sustainable use of green roofs, it has turned into a space that provides both a living room outside the building and a movement area. Thanks to these features, the concepts of the green roof have become ecologically, economically, and socially significant and its classical definition.

The results for green roofs show less heat transfer than terrace roof, which is due to the use of conductive materials such as filter layers. It should be noted that the conductivity of the culture medium (plant) and drainage layer is higher in the wet state.
In the two types intended for green roofs (extensive and intensive), the main difference is the thickness of the soil and, consequently, water insulation. Therefore, heat transfer from the roof in the intensive type is relatively reduced compared to the extensive type. Considering the contribution of green roofs to energy consumption, the Bartın University Life Center building, which was built with a flat terrace roof, was modeled with extensive and intensive green roofs, and energy consumption rates were discussed. According to the results obtained by comparing the energy simulation graphics in the EGR and IGR applications, the green roof type cooling loads are reduced by up to $57 \%$ compared to the terrace type, and the total carbon dioxide production is reduced by $82 \%$ by reducing the heating load of the building by up to $20 \%$. There was no significant difference between the intensive and the extensive types, but the intensive type showed better results than the extensive type.

The increase in energy performance in buildings with green roof, is due to the isolation effect of the soil on the roof. Roof and floor slabs are the building elements where the heat loss of the building occurs the most. The heated air rises and forces it to come out from the roof floor, and heat losses occur in the structure. If there is no thermal insulation on the roof, these losses become more evident. For this reason, green roofs increase energy gain by preventing losses from the roof in buildings. Replacing the polystyrene foam used in the structure selected within the scope of the study with another thermal insulation material or increasing its thickness may lead to a further improvement in energy performance with green roofs. In future studies, scenarios for the integration of green roof types with different thermal insulation materials will be able to answer these questions. In addition, the economy and longevity of both roof types will be discussed in future research, and a double-confirmed decision can be made about these two roof types according to the results.

\section{Conflict of Interest Statement}

The authors declare no conflict of interest.

\section{References}

[1] C. Werthmann, Green Roof-A Case Study: Michael Van Valkenburgh Associates' Design for the Headquarters of the American Society of Landscape Architects. 2007: Princeton Architectural Press.

[2] R.K. Sutton, Introduction to green roof ecosystems, in Green Roof Ecosystems. 2015, Springer. 1-25.

[3] K. Vijayaraghavan, Green roofs: A critical review on the role of components, benefits, limitations and trends. Renewable and sustainable energy reviews 57 (2016) 740-752.

[4] I. Teotónio, C.M. Silva, C.O. Cruz, Eco-solutions for urban environments regeneration: The economic value of green roofs. Journal of Cleaner Production 199 (2018) 121-135.

[5]T. Carter, A. Keeler, Life-cycle cost-benefit analysis of extensive vegetated roof systems. Journal of environmental management 87 (2008) 3 350-363.

[6] N. Tohum, Sürdürülebilir Peyzaj Tasarım Aracı Olarak Yeşil Çatılar (Green Roofs As Sustainable Landscape Design Tools), Master Thesis, Institute of Science and Technology 2011, Istanbul Technical University, Istanbul. 
[7] J. Zuo, Z.Y. Zhao, Green building research-current status and future agenda: A review. Renewable and Sustainable Energy Reviews (2014) 30 271-281.

[8]WBCSD, Energy efficiency in buildings: Business realities and opportunities. 2007, World Business Council on Sustainable Development.

[9] F. A. Rahman, M M. A. Aziz, R. Saidur,W.A. Bakar, M. R. Hainin, R. Putrajaya, N.A. Hassan Pollution to solution: Capture and sequestration of carbon dioxide $\left(\mathrm{CO}_{2}\right)$ and its utilization as a renewable energy source for a sustainable future Renewable and Sustainable Energy Reviews 71 (2017) $112-126$.

[10] G.A. Olah, G.S. Prakash, A. Goeppert, Anthropogenic chemical carbon cycle for a sustainable future. Journal of the American Chemical Society 133 (2011) 33 12881-12898.

[11] F.A. Memon, D. Butler, Water consumption trends and demand forecasting techniques. Water demand management (2006) 1-26.

[12] A. Shahteymuri, M. Naaranoja, Analysis of Diffusion of Biomass Energy Utilization. Computational Research Progress in Applied Science \& Engineering 2 (2016) 3 101105.

[13] C.R Lohri, E.J. Camenzind, C. Zurbrügg, Financial sustainability in municipal solid waste management - Costs and revenues in Bahir Dar, Ethiopia. Waste Management 34 (2014) 542-552.

[14] G. Bel, M. Warner, Does privatization of solid waste and water services reduce costs? A review of empirical studies. Resources, Conservation and Recycling 52 (2008) 121337 1348.

[15] S.L. Lim, L.H. Lee, T.Y. Wu, Sustainability of using composting and vermicomposting technologies for organic solid waste biotransformation: recent overview, greenhouse gases emissions and economic analysis. Journal of Cleaner Production (2016) 111 262-278.

[16] USGBC, L. and G.B. Design, Construction Reference Guide. 2014, USGBC.

[17] B. Kobaş, Oluşturulmakta olan Türk yeşil bina değerlendirme sisteminin malzeme kategorisi için BREEAM ve LEED örneklerinin incelenmesi (Evaluating Breeam And Leed's Building Material Credits In Order To Form A Roadmap For Turkish Green Building Assessment System), Master Thesis, in Institute of Science and Technology. 2011, Istanbul Technical University, Istanbul.

[18] B. Yan, The research of ecological and economic benefits for green roof. Applied Mechanics and Materials 71 (2011) 27632766.

[19] M. Köhler, M. Schmidt, F.W. Grimme, M. Laar, V.L. Assunçao Paiva, S. Tavares, Green roofs in temperate climates and in the hot-humid tropics-far beyond the aesthetics. Environmental management and health, (2002).

[20] E. Erkul, A. Sönmez, Yeşil Çatı Sistemleri ve Çevresel Etkileri (in Turkish) Mimarlık Dergisi 375 (2014) 52-58.

[21] N. Dunnett, N. Kingsbury, Planting green roofs and living walls. 2008: Timber press Portland, OR.

[22] C.Y. Jim, S. Tsang, Modeling the heat diffusion process in the abiotic layers of green roofs. Energy and buildings 43 (2011) 1341-1350.

[23] C.S. Smith, Differing Interpretations of Sustainability and Natural Resource Management in Three Adjacent Communities in the Oregon Cascades. 2010: University of Washington.

[24] J.C. Berndtsson, Green roof performance towards management of runoff water quantity and quality: A review. Ecological engineering, 36 (2010) 4 351-360.

[25] D.S. Canım, Ö. Aydın, Energy performance evaluation of energy performance calculation method in buildings (BepTr1). Journal of Construction Engineering 2 (2019) 18-29.
[26] F. Bianchini, K. Hewage, How "green" are the green roofs? Lifecycle analysis of green roof materials. Building and environment 48 (2012) 57-65.

[27] B.S. Qurraie, F. Beyhan, Using a Shading Tool to Reform Window designing due to Solar Radiation, International Journal of Advanced Research in Enginnering 4 (2018) 1-6.

[28] J. Breuste, M. Artmann, J. Li, M. Xie, Special issue on green infrastructure for urban sustainability, Journal of Urban Planning and Development 141 (2015) A2015001.

[29] J. Foster, A. Lowe, S. Winkelman, The value of green infrastructure for urban climate adaptation. Center for Clean Air Policy 750 (2011) 1-52.

[30] C.G. Wark, W.W. Wark, Green roof specifications and standards. Construction Specifier 56 (2003) 8.

[31] M. Shafique, R. Kim, M. Rafiq, Green roof benefits, opportunities and challenges-A review. Renewable and Sustainable Energy Reviews 90 (2018) 757-773.

[32] S. Tabasi, A. Aslani, H. Forotan, Prediction of energy consumption by using regression model. Computational Research Progress in Applied Science \& Engineering 2 (2016) $110-115$.

[33] R. Fernandez-Cañero, T. Emilsson, C. Fernandez-Barba, M.A.H. Machuca, Green roof systems: A study of public attitudes and preferences in southern Spain. Journal of Environmental Management 128 (2013) 106-115.

[34] İ. Ayçam, M. Kınalı, Ofis Binalarında Yeşil Çatıların Isıtma ve Soğutma Yüklerine Olan Etkilerinin Analizi (in Turkish). Tesisat Mühendisliği Dergisi 135 (2013) 26-34.

[35] A. Spala, H.S. Bagiorgas, M.N. Assimakopoulos, J. Kalavrouziotis, D. Matthopoulos, G. Mihalakakou, G. On the green roof system. Selection, state of the art and energy potential investigation of a system installed in an office building in Athens, Greece. Renewable Energy 33 (2008) 173177.

[36] I., Ziogou, A. Michopoulos, V. Voulgari, T. Zachariadis, Energy, environmental and economic assessment of electricity savings from the operation of green roofs in urban office buildings of a warm Mediterranean region. Journal of cleaner production 168 (2017) 346-356.

[37] J.H., Kim, K.U. Kwon, C.H. Joo, Y.H. Yoon, Comparative of energy-saving by green roof type on urban office building. Journal of Environmental Science International 23 (2014) $1437-1446$.

[38] P. Karachaliou, M. Santamouris, H. Pangalou, Experimental and numerical analysis of the energy performance of a large scale intensive green roof system installed on an office building in Athens. Energy and Buildings 114 (2016) 256264.

[39] N. H. Wong, Y. Chen, C.L. Ong, A. Sia, Investigation of thermal benefits of rooftop garden in the tropical environment. Building and environment 38 (2003) 261-270.

[40] D.J. Sailor, A green roof model for building energy simulation programs. Energy and buildings 40 (2008) 1466-1478.

[41] S. Onmura, M. Matsumoto, S. Hokoi, Study on evaporative cooling effect of roof lawn gardens. Energy and buildings 33 (2001) 653-666.

[42] A. Niachou, K. Papakonstantinou, M. Santamouris, A. Tsangrassoulis, G. Mihalakakou, Analysis of the green roof thermal properties and investigation of its energy performance. Energy and buildings 33 (2001) 7 719-729.

[43] I. Jaffal, S.-E. Ouldboukhitine, R. Belarbi, A comprehensive study of the impact of green roofs on building energy performance. Renewable Energy 43 (2012) 157-164.

[44] S. Frankenstein, G. Koenig, FASST vegetation models. 2004, Engineer Research And Development Center Hanover Nh Cold Regions Research. 1-56.

[45] E.P. Del Barrio, Analysis of the green roofs cooling potential in buildings. Energy and buildings 27 (1998) 179-193. 
[46] T.G. Theodosiou, Summer period analysis of the performance of a planted roof as a passive cooling technique. Energy and buildings 35 (2003) 909-917.

[47] M. Santamouris, C. Pavlou, P. Doukas, G.Mihalakakou, A. Synnefa, A. Hatzibiros, P. Patargias, Investigating and analysing the energy and environmental performance of an experimental green roof system installed in a nursery school building in Athens, Greece. Energy 32 (2007) 1781-1788.

[48] Bartın Üniversitesi. Yapı İşleri ve Teknik Daire Başkanlığı 2020 [cited 2021 23.12.2012]; Available from: https://yapiisleri.bartin.edu.tr/devam-edenprojelerimiz/ogrenci-yasam-merkezi-ve-hafriyat-isi.html.

[49] T. Van Renterghem, D. Botteldooren, In-situ measurements of sound propagating over extensive green roofs. Building and Environment 46 (2011) 729-738.

[50] M. Squier, C.I. Davidson, Heat flux and seasonal thermal performance of an extensive green roof. Building and Environment 107 (2016) 235-244.

[51] G. Pérez Luque, A. Vila, L. Rincón, C. Solé Cutrona, L.F. Cabeza, Use of rubber crumbs as drainage layer in green roofs as potential energy improvement material. Applied Energy 97 (2012) 347-354

[52] A. Nagase, Novel application and reused materials for extensive green roof substrates and drainage layers in Japan Plant growth and moisture uptake implementation, Ecological Engineering 153 (2020) 105898.

[53] Y. He, H. Yu, N. Dong, H. Ye, Thermal and energy performance assessment of extensive green roof in summer: A case study of a lightweight building in Shanghai. Energy and Buildings 127 (2016) 762-773.

[54] J. Coma Arpón, G. Pérez Luque, C. Solé Cutrona, A. Castell, L.F. Cabeza, Thermal assessment of extensive green roofs as passive tool for energy savings in buildings. Renewable Energy 85 (2016) 1106-1115.

[55] N.S.A. Asman, S. Dullah, J.L. Ayog, A.K. Mirasa, H. Djamila, The hydrological performance of lightweight green roofs made from recycled waste materials as the drainage layer. in MATEC Web of Conferences. (2017). EDP Sciences.

[56] A.F. Speak, J.J. Rothwell, S.J. Lindley, C.L. Smith, Rainwater runoff retention on an aged intensive green roof. Science of the Total Environment 461 (2013) 28-38.

[57] E. Korol, N. Shushunova, Benefits of a Modular Green Roof Technology. Procedia Engineering, 161 (2016) 1820-1826.

[58] C.Y. Jim, S. Tsang, Biophysical properties and thermal performance of an intensive green roof. Building and Environment 46 (2011) 6 1263-1274.

[59] Y. Xing, P. Jones, In-situ monitoring of energetic and hydrological performance of a semi-intensive green roof and a white roof during a heatwave event in the UK. Indoor and Built Environment, (2019) 1420326X19887218.

[60] H. Turoğlu, İklim değişikliği ve Bartın Çayı Havza yönetimi muhtemel sorunları (in Turkish). Coğrafi Bilimler Dergisi 12 (2014) 1-22.

[61] A. Tindale, Designbuilder software. Stroud, Gloucestershire, Design-Builder Software Ltd, (2005). 